7. Knyha vrazhen ta pobazhan Muzeiu ukrainskoho rushnyka za 1995-2002 rr. [The Book of Impressions and Wishes of the Ukrainian Towel Museum for 1995-2002].

8. Makhinchuk, M. G. (1998). Oberehy nashoi pam'iati: Knyha dlia chytannia z istorii Ridnoho kraiu [Savers (Oberig) of our memory: A book for reading on the history of the Native land] / Preface by I. F. Drach. Odessa: RBA «Aspect».

\title{
THE PIANO FANTASIES BY V.A. MOZART IN THE CONTEXT OF PHILOSOPHICAL AND POETIC CONCEPTS OF IMAGINATION
}

\section{Elena Pogoda ${ }^{1}$}

DOI: https://doi.org/10.30525/978-9934-588-11-2_26

By the end of the 18th century, the phenomenon of fantasy receives multifaceted understanding, while being developed as a philosophical category and as a genre that embraces music, literature, poetry, theatre, and visual arts.

The philosophical development of imagination and fantasy of the end of the 18 th century can be found in the works by I. Kant of 1781-1798 [1], the first of which was written almost simultaneously with the piano fantasies by V.A. Mozart. I. Kant identifies the types of fantasies that manifested themselves in music. Such are fantasy as contemplation (a contemplative beginning is inherent in fantasy), a dream (its characteristic features are fragmented kaleidoscopic images), playing (a playing method as a way to create an artistic image - the fundamental one for fantasy). The functions of fantasy - illusory, transforming, associative, transcendental, synthesizing, were embodied in the creative work of V.A. Mozart.

In the theory of literature at the end of the 18th century, the concepts of fantasy as a fundamental type of artistic creation were developed in the legacy of English romantics - S.T. Coleridge and W. Wordsworth. Imagination is the ability to synthesize perceptions of various kinds. The function of fantasy, according to S.T. Coleridge is in "collecting the diverse experiences of being according to the laws of associations» [2, p. 28]; fantasy is the ability to bring together images that do not have natural connections, but are connected by a poet «according to the principle of a random coincidence» [2, p. 62]. Imagination «modifies images, gives unity to diversity and focuses everything in one». W. Wordsworth notes that fantasy «helps to comprehend the essence of things and characters immeasurably deeper» [3, p. 142]. The piano fantasies by V.A. Mozart were created during the last - the climax of the composer's creative work. The fantasy trilogy of 1782 (fantasy and fugue C-dur $394 \mathrm{KV}$, fantasy c-moll $396 \mathrm{KV}$ and d-moll $397 \mathrm{KV}$ ) marked the beginning of a mature stage in the composer's creative work, the fantasy and sonata c-moll of $1785(475 \mathrm{KV})$ coincided with the era of writing opera masterpieces (the end of the work on «The Wedding of Figaro» and the beginning of work on «Don Juan»).

${ }^{1}$ Kharkiv National Kotlyarevsky University of Arts, Ukraine 
The only major fantasy by V.A. Mozart is the «heiress» of the baroque interpretation of the genre. Its prototypes are the polyphonic diptych by I.S. Bach and the new synthesized form of fantasy created by F.E. Bach. Despite the fact that all the fantasies by V.A. Mozart, starting with the c-moll of 1782, represent the progress of the development of the genre proposed by F.E. Bach, each of them is distinguished by an individualized artistic solution. All the four piano fantasies by V.A. Mozart is consistent with the Kantian definition of fantasy as contemplation and dreaming. At the same time, each of them represents a peculiar type of interpretation of contemplation. According to the type of content, c-moll fantasy should be defined as contemplation, the subject of which is the universe. Fantasy d-moll embodies a variety of types of contemplation, characterizing both the state of the subject of contemplation (the hero of the composition) and its object (the object of contemplation). The subject of contemplation is distinguished by its types such as contemplation-action, contemplation-joy; the object of contemplation embraces the earthly and heavenly, as a result of which the connection is established between the micro- and macrocosm. Fantasy d-moll embodies the controversy of contemplation arising from the invasion of the fateful beginning into the ideal world. Fantasy cmoll, preceding the sonata, consists of six sections, each of which represents a special type of contemplation, which allows us to interpret the composition as a cycle of fantasies (pre-romantic interpretation of the genre).

In the Mozart interpretation of fantasy as contemplation and dreaming the leading romantic categories, ways of knowing the universe - the insight of the Viennese genius into the field of the art of the future lies. The provisions of the concept of imagination, developed in the philosophical works by I. Kant and the literary and poetic views of S.T. Coleridge and W. Wordsworth within twenty years, find concentrated refraction in the music created by V.A. Mozart. This is the evidence of the unity of philosophical and artistic understanding of the fantasy of the era of pre-romanticism.

\section{References:}

1. Kant, I. (1966). Sochineniya. V 6 tomakh [Compositions. In 6 volumes]. Moskva: Mysl'. (in Russian)

2. D'yakonova, N. Ya. (1978). Angliyskiy romanizm [English romance]. Moskva: Nauka. (in Russian)

3. Elistratova, A. A. (1960). Nasledie angliyskogo romantizma i sovremennost' [The legacy of English romanticism and modernity]. Moskva: izdatel'stvo Akademii nauk SSSR. (in Russian)

4. Abert, G. (1985). V. A. Motsart [V.A. Mozart]. Moskva: Muzyka. (in Russian)

5. Medushevskiy, V. V. (1991). Fantaziya v kul'ture i muzyke [Fantasy in culture and music]. Muzyka, kul'tura, chelovek, vol. 2, pp. 44-56.

6. Roshchenko, E. G. (2004). Novaya mifologiya romantizma $i$ muzyka (problemy entsiklopedicheskogo analiza muzyki) [The new mythology of romanticism and music (problems of the encyclopedic analysis of music)]. Khar'kov: KhNURE. (in Russian) 